\title{
THE FAMILY PLANNING PROGRAM ACCEPTORS' ATTITUDE AND BEHAVIOR TO OVERCOME THE SIDE EFFECTS OF CONTRACEPTIONS
}

\author{
Sukmawati $^{1}$, Lilis Mamuroh ${ }^{1}$, Furkon Nurhakim $^{1}$, Tetti Solehati ${ }^{1}$ \\ Faculty of Nursing Universitas Padjadjaran \\ Correspondance: Ahmad.sukma@yahoo.co.id
}

\begin{abstract}
The contraceptive injection is one of the most widely used contraceptives by family planning acceptors in Garut Regency, especially in the Bayongbong Village. Side effects of the contraceptive injection include: amenorrhea, galactorrhea, bleeding, spotting, headache, lower abdominal pain, depression, hirsutism, hypertension, jaundice, decreased libido, nausea, dizziness, anxiety, thrombophlebitis, and weight gain and loss. The side effects of the contraceptive injection, if not addressed, would cause a drop out of acceptors of the family planning program. The attitudes and actions of family planning acceptors are one of the factors that influence the decision of the acceptors to continue to become the contraceptive injection acceptors or drop out. The purpose of this study was to determine the attitudes and actions of 3-month the contraceptive injection acceptors in overcoming side effects in the Bayongbong Village, Garut. The research method was descriptive, the sample of research was 72 people selected by random sampling technique. The analysis used was univariate. The results showed that 27 respondents $(37.5 \%)$ had an unsupportive attitude and 45 people $(62.5 \%)$ had a supportive attitude. While the actions of 32 people $(44.4 \%)$ had good actions and 40 people $(55.6 \%)$ had less action in overcoming the effects of 3 months injection of the family planning program. The side effects of the 3-month injection contraception device are one of the factors that can influence the decision to continue using contraception or not. Most respondents had non-supportive attitudes and fewer actions in overcoming side effects.
\end{abstract}

Keywords: Side effect, injectable contraception, attitude, behavior

\section{INTRODUCTION}

Indonesia still has problems with population growth, the estimated population in Indonesia in 2016 reached 258,704,986 people. Population growth continued to increase from 2012-2014, which was 3.59 million per year to 3.70 million per year. In 2016 there was a slight decline from 2015, which was 3.24 million per year. The population in West Java in 2016 ranked first with 47,379,389 people (Ministry of Health, 2017). While the population in Garut Regency is 2,569,505 people (Garut District Health Office, 2016). Family Planning is one way to control population growth while family planning is an effective way to improve maternally and child health. Family Planning protects mothers from high-risk pregnancies, saves lives and reduces morbidity rates (Hartarto, 2010). Family planning is an attempt to control the amount of population so that it does not bring disadvantage to anyone such as the mother, baby, father, family or community 
due to the birth of the baby. (Iriato, 2014). Family planning is an effort to create a quality family through promotion, protection, and assistance in realizing reproductive rights. Family planning also organizes services, arrangements, and support to form an ideal marriage age families, control the number, age difference, and ideal age for childbirth, control pregnancy and fosters child resilience and welfare (BKKBN: 2015). One way to implement a family planning program is to use contraception. Contraception is a method to prevent conception or pregnancy so that couples could plan the number of children and the desired age distance of pregnancy. Various contraceptives used in implementing family planning include birth control pills, injections, condoms, IUDs, implants, vasectomy and tubectomy, topical drugs intra vagina which kills sperm (Prawirohardjo, 2009). Injection contraception is a contraceptive that is in great demand by family planning acceptors in Indonesia, the data shows a significant increase of $11.7 \%$ in the 1991 IDHS to $31.7 \%$ in the 2017 RPJMN (Gerintya, 2018).

The use of the contraceptive injection in 2016 in Garut Regency was (51.64\%) and in Bayongbong District 56.91\% acceptors (Garut District Health Office, 2017). There is no perfect contraception seen from the effectiveness and side effects, each contraception device has its advantages and disadvantages so that the use of contraception must be adjusted to the patient's condition (Ralph and Benson, 2008). Side effects of the contraceptive injection include: amenorrhea, galactorrhea, bleeding, spotting, headache, lower abdominal pain, depression, hirsutism, hypertension, jaundice, decreased libido, nausea, dizziness, anxiety, thrombophlebitis, weight gain and loss (Wiknajosastro, 2010 )

The side effects of a contraceptive method are one of the factors that could affect the acceptor to continue using the contraceptive injection or not, besides the side effects could also influence the level of satisfaction in using injection contraceptives. The number of side effects that are often experienced by acceptors and if not addressed causes the acceptor to drop out. The attitudes and actions of family planning acceptors are one of the factors that can influence the decision of acceptors to continue to become injectable acceptors or drop out. Attitude is a closed response to the stimulation of an object and readiness to react to the object as a form of appreciation of the object (Notoatmodjo, 2010). According to 
Mubarok (2009) attitudes can be influenced by one's experience so that attitudes are more easily formed with experiences. The experience of acceptors who experienced side effects tends to form a non-supportive attitude towards the use of contraceptive, otherwise, if the acceptors experiencing minimal and resolved side effects, they will form a supportive attitude towards the use of injectable contraceptives. An attitude has not been automatically realized in an action, to realize an attitude into an action required supporting factors or a condition that allows such factors as facilities and factors of support from other parties (Notoatmodjo, 2010). The purpose of this study was to find out the attitudes and actions of 3-month the contraceptive injection acceptors in overcoming the side effects of it.

\section{METHODS}

The method in this study was descriptive. The study population was 2593 -month injection contraception active acceptors with a total sample of 72 people, while the sampling technique in this study was a random sampling. Univariate analysis was used to determine the attitudes and actions of 3-month the contraceptive injection acceptors in overcoming side effects.

\section{RESULTS}

The results of the study conducted in the Bayongbong Village, Bayongbong Subdistrict, Garut Regency, used primary data with the technique of collecting interview data on respondents in September 2017. The results of the study can be seen in the following table below:

Table 1 Attitude of 3-month the contraceptive injection Acceptor in Overcoming Side Effects in Bayongbong Village, Bayongbong District, Garut Regency

\begin{tabular}{lcc}
\hline \multicolumn{1}{c}{ Attitude } & Frequency & $\%$ \\
\hline Support & 45 & 62,5 \\
\hline Does not support & 27 & 37,5 \\
\hline Total & 72 & 100 \\
\hline
\end{tabular}


Table 1 shows that of the 72 respondents most of them had the attitude of supporting 45 people $(62.5 \%)$ and a small portion of 27 respondents $(37.5 \%)$ did not support.

Table 2 Behavior of 3-Month the contraceptive injection Acceptor in Overcoming Side Effects in Bayongbong Village, Bayongbong District, Garut Regency

\begin{tabular}{|c|c|c|}
\hline Behavior & Frequency & $\%$ \\
\hline Good & 32 & 44,4 \\
\hline Poor & 40 & 55,6 \\
\hline Total & 72 & 100 \\
\hline
\end{tabular}

Table 2 shows that from 72 respondents, a small portion had good behavior 32 people (44.4\%) and most 40 respondents $(55.6 \%)$ had poor behavior.

\section{DISCUSSION}

Contraception is an attempt to prevent the occurrence of pregnancy that is temporary or permanent (Wiknjosastro, 2010). The way injection contraception work include preventing ovulation, thickening the cervical mucus, uterine mucous membranes becoming thinner and atrophy and inhibiting the transport of sperm to the tube (Arum and Sujiantini, 2009). Each contraceptive has side effects as well as 3-month injection contraception including menstrual disorders caused by a decrease in the estrogen hormone caused by thinner endometrial walls, increased weight and so on (Hartanto, 2010). The side effects of 3-month the contraceptive injection experienced by acceptors is the anxiety of the acceptor so that the acceptor can make a decision to continue or stop the contraceptive injection depending on the motivation and experience of the side effects experienced by the acceptor (Prita and Kinesti, 2013) If these side effects are not immediately addressed, this will affect the continuity of the use of contraception. To overcome side effects is influenced by various factors including how the attitude and actions of the acceptor in overcoming side effects. 
Attitude is a reaction or response that is still sealed from someone to the stimulus of an object. In this attitude, there are 3 main components, namely belief, emotional life and tendency to act (Notoatmodjo, 2010). The results showed that $37.5 \%$ of acceptors had a less supportive attitude in overcoming the side effects of 3-month the contraceptive injection, this could affect the continuity of family planning program injection acceptors to continue using injection this is in line with the theory of Middlebrook (1974) in Mubarak (2009) that the absence of experience in a psychological object tends to form a negative attitude towards the object, which is the basis for forming attitudes, personal experiences, and a deep impression on those concerned. Various efforts can be made to change a person's attitude, including providing adequate information, this is in line with the opinion of Sarwono (1997) in Maulana (2009) that a person's attitude can change by obtaining additional information through persuasion with pressure from social groups. This is in line with the results of Darmawati (2011) research on factors that influence fertile age in choosing the contraceptive injection in addition to education, socio-economic, contraceptive services and family support are also influenced by the attitude of the acceptor itself. The attitude will not automatically become behavior or action because there are other factors that influence including support from other parties, knowledge, and attitudes towards what is done are factors that can facilitate the occurrence of actions (Nikmawati, 2017).

\section{CONCLUSION}

Most of the 3-month the contraceptive injection acceptors have a supportive attitude in overcoming side effects, but a small number of actions taken by 3 month the contraceptive injection acceptors are still lacking in overcoming side effects. Family planning program acceptors are expected to inject 3 months intensively to get counseling from health workers about the side effects that will be experienced and how to overcome them, and the contraceptive injection acceptors keep the schedule when they will repeat injections.

\section{REFERENCES}

Arum dan Sujiantini. (2009). Panduan Lengkap Pelayanan KB Terkini. Yogyakarta : Nuha Medika 
Sukmawati : The Family Planning Program Acceptors' Attitude And Behavior

BKKBN. (2015). Rencana Strategis Badan Kependudukan dan Keluarga Berencana Nasional. Jakarta : BKKBN

Darmawati. (2011). Faktor-faktor Yang Mempengaruhi Wanita Usia SuburMemilih Kontrasepsi Suntik. www.jurnal.unsyiah.ac.id/IN/article/view/6354/5220

Dinas Keshatan Kabupaten Garut. (2017). Profil Kesehatan Kabupaten Garut 2016. Garut:2017

Gerintya, S (2017). Waspada Program KB : Pengguna Alat Kontrasepsi Turun Pada 2017. International Fact-Chacking Network@Pointer.Signatory

Hartarto, H. (2010). Keluarga Berencana Dan Kontrasepsi (KB). Jakarta : Sinar Harapan

Irianto, K. (2014). Pelayanan Keluarga Berencana. Bandung : Alfabeta

Kementerian Kesehatan RI. (2017). Profil Kesehatan Indonesia 2016. Jakarta : Kemenkes

Maulana. (2009). Promosi Kesehatan. Jakarta : EGC

Mubarak, I. (2009). Ilmu Keperawatan Komunitas Pengantar dan Teori. Jakarta : salemba

Nikmawati, N. (2017). Faktor-faktor Yang Berhubungan Dengan Penggunaan Metode Kontrasepsi Jangka panjang. Jurnal Bidan Volume 6 No 12 April 2017 ISSN 2089-7669

Notoatmodjo, S. (2010). Promosi Kesehatan Dan Perilaku. Jakarta : Rineka Cipta

Prawiroharjo, S. (2009). Keluarga Berencana dan Kontrasepsi. Jakarta : yayasan Bina Pustaka Sarwono Prawiroharjo

Prita, D dan Kinesti, N. (2013). Sikap Ibu Terhadap Efek samping KB Suntik 3 Bulan Di Desa Bakalanrayung Kecamatan Kudu. http://stikespemkabjombang.ac.id/ejurnal/index.php/April2013/article/view/23/39 
Sukmawati : The Family Planning Program Acceptors' Attitude And Behavior

Ralph, C. Dan Benson. (2008). Buku Saku Obstetri dan Ginekologi. Edisi 9. Jakarta : EGC

Wikjosastro. (2010). Ilmu Kebidanan. Jakarta : Yayasan Bina Pustaka 